\title{
Investigating the Effects of Active Learning Strategies on Problem Solving.: A Quasi-Experimental Study in Cycle Two
}

\author{
Lina Amanatallah ${ }^{1,2 *} \quad$ Nehme Safa ${ }^{2}$ \\ 1.School of Education, Lebanese International University, Tripoli, Lebanon \\ 2.Department of Educational Sciences, Saint-Joseph University, Beirut, Lebanon
}

\begin{abstract}
Problem-solving, being one major aspect of our daily activities, is often considered by students worldwide as the most difficult domains in mathematics. In Lebanon, like many other countries, problem-solving is a major aspect in the mathematics curriculum which requires students to apply and to integrate many mathematical concepts and skills as well as making decisions. However, the absence of national and international statistics of Lebanese elementary students' performance in problem solving (PS) challenged the researchers to consider teaching strategies that give the students the chance to play an active role in their learning, and thus improve their performance in PS. Therefore, this article reports on a part of a larger mixed-methods, quasi-experimental study which investigated the effect of implementing Active Learning Strategies (ALS) mainly Think/Pair /Share (TPS), Socratic Questioning (SQ), and Inquiry based Learning (IBL) on students' performance in problem solving (PS) in Grade 4, 5, and 6. $(\mathrm{n}=454)$ in three private schools in Tripoli- Lebanon. After assigning students and teachers to experimental and control groups, teachers in the experimental group participated in an intensive training on the use of ALS and implemented them over a three months period. The researcher used the t-test to compare the pre- and post-scores of both groups on mathematics PS. Findings indicated that experimental group students outperformed control group students on problem solving. Recommendations for continuous professional development for educators and for further research were also provided.
\end{abstract}

Keywords: Active learning strategies, Mathematics problem-solving, Elementary, IBL, TPS, SQ

DOI: $10.7176 / \mathrm{JEP} / 12-17-05$

Publication date:June $30^{\text {th }} 2021$

\section{Introduction}

Early success in mathematics is important because it is a strong predictor of later achievement in school (Morgan, Farkas, \& Wu, 2011), and mathematics success leads to increased college and career opportunities (Murnane, Willett, Braatz, \& Duhaldeborde, 2001).Moreover, solving mathematical problems is thought to be at the heart of mathematics education and is "perhaps the most significant activity in the teaching of mathematics" (Curriculum Document, 1997.p. 228-289). However, it is often considered by students as one of the most frustrating domains, and students worldwide are reported to have difficulties in mathematics problem solving (Mikati, 2017; Tambychik, Meerah \& Aziz, 2010). The difficulties were related to difficulties in understanding the mathematical problem, devising a suitable strategy to solve it, carrying out a plan to implement the suitable strategy, conducting deductive reasoning, understanding-applying mathematical concepts, comprehending mathematical texts, and writing mathematical texts. These difficulties varied in their level from one grade level to another and according to the proof and language complexity levels of the proof tasks (Mohd Johan, 2002; Heong, 2005; Tarzimah, 2005; Zalina, 2005 - cited in Tambychik, Meerah \& Aziz, 2010; Al-Masri, 2013; Mikati, 2017). Due to these persisting difficulties, calls for instructional reform in mathematics have been accompanied by demands in many countries for radical changes in mathematics teaching practices (Steinberg, Empson, \& Carpenter, 2004).

In Lebanon, students in Lebanese schools also face difficulties in solving mathematics problems (Al-Masri, 2013; Mikati, 2017; Mahfouz 2018), and Lebanese secondary teachers complain that students reach Grade 12 and are still unable to think logically; they rely on memorization to solve problems (Mahfoud, 2018). Moreover, the results of Lebanese students' in international exams such as PISA and TIMSS, which assess problem solving, showed low scores compared to other countries. For instance, Lebanese eighth-graders with mean scores of 433 (2003), 441 (2007), 449 (2011), 442 (2015), and 429 (2019) were placed 31, 28, 25, 58 and 32 among 45, 48, 63, 76 and 39 countries respectively (TIMSS \& PIRLS, 2016; Harmouch, Khraibani \& Atrissi 2017, TIMSS \& PIRLS, 2019). Similarly, in PISA 2015, 15-year-old Lebanese students scored 396 points in mathematics compared to an average of 490 points in OECD countries (OECD, 2000). Lately, in PISA 2018, 15-year-old Lebanese students scored 393 points in mathematics compared to an average of 460, and ranked 67 among 77 participating countries (CRDP, 2019).

The above results showed Lebanese students' deficiency in problem solving and since problem-solving skill is the corner stone for elementary students to pursue mathematics learning in the successive grade levels, Lebanese elementary students should possess this skill to maintain their future success in mathematics. Active learning strategies have been proven to be successful in developing students' problem-solving skills (Al- 
Alloul,2012; Farajallah,2017). Hence there is a need to investigate the effect of active learning strategies on enhancing Lebanese students' performance in problem-solving.

\section{Theoretical Framework. and Literature Review}

The idea of active learning (AL) was first developed by the philosopher Jean-Jacques Rousseau (1712-1778) and influenced numerous educators in the early 20th century such as John Dewey (1859-1952) and Maria Montessori (1870-1952) and led to inquiry-based and discovery learning models as stated by Fisher (2002). The main idea is that one learns best when he/she can see the usefulness of what one learns, connects it to the real world, and interacts with others. Being active is what causes children both physically and cognitively to construct their own view of the world, to personalize the experience and to apply it in ways that make sense to them as individuals (Bruner \& Haste, 1987).

Theories in relation to active learning such as constructivism, rooted in Jean Piaget's (1976) work, and social constructivism, rooted in the work of Lev Vygotsky (1986), suggest that children are active learners and their cognitive development occurs through social experiences with others, especially those who can help them expand their thinking or other skills with "scaffolded" interaction and support given at the right time (Kearsley, 1993; Eggen \& Kauchak, 2013). Therefore, social interaction is essential for learning to occur, and the nature of the community of learners is affected by not just the culture the teacher creates, but by the broader social and historical culture of the members of the classroom (Forman \& McPhail, 1993). For Bronfenbrenner 's EST (1979), children learning is influenced by their environment, and the effect of culture and society on children learning. Therefore, the process of teaching and learning in general, including problem-solving, is affected by maturation in addition to the interactions between students, teachers, parents, administrators, stake holders and society in general; any disequilibrium in the relation between two of them will affect the teaching learning process automatically (Bronfenbrenner, 2004). Therefore, teachers or adults' knowledge and learning play a critical role as well.

In the context of adult learning, a number of theories were taking adult needs and motivation into consideration. The theories include Maslow's hierarchy of needs and Knowles's theory of Andragogy (Moukarzel, 2011). Based on these theories, studies showed that teachers' professional development program (PD) improves teachers' performance to a good extent as well as students' participation (Moukarzel, 2011; Callingham, 2015). Therefore, from a constructivist and social constructivist perspective, Mathematics' teachers'PD should stress the importance of social interaction in teaching Mathematics and include active learning strategies that give students an active role in constructing their own understanding.

\subsection{Active Learning}

During active learning, students can monitor their own progress and understanding. They "become aware of their progress and can be actively involved in finding solutions when they struggle with a particular aspect of the task" (Monk and Silman, 2013. P.35). Van De Walle, Karp, \& Bay-Williams (2016) mention the importance of "productive struggle" in solving mathematical word problems (Van De Walle, Karp, \& Bay-Williams, 2016. p.15). They believe that the teacher should not step in and show how to solve a problem as soon as a student pauses. While this may initially get the student to an answer faster, it does not help the student learn mathematics. Engaging in productive struggle is what helps students learn mathematics.

Moreover, monitoring ones' understanding involves metacognition. Metacognition involves analyzing the way that thinking takes place (Brown, 1987; Campione, Brown, \& Connell, 1989; Garofalo \& Lester, 1985; Kilpatrick, 1985; Schoenfeld, 1985). And because metacognition is connected to learning (Brandsford, Brown, \& Cocking, 2000), and it is a behavior that can be learned (Campione, Brown, \& Connell, 1989; Garofalo, \& Lester, 1985), making it a part of classroom discourse is one way to make it happen.

In addition to that, according to Hart, Dixon, Drummond and McIntyre (2004), self-awareness enhances metacognition; thus, learners need to acquire self-awareness skills to move on in active learning. Self-awareness refers to the capacity of becoming the object of one's own attention (Duval \& Wicklund, 1972). Claxton (2008) refers to self-awareness as 'building learning power,' which includes helping children not necessarily to learn more, but to become better learners. For this purpose and for students to gain insight into their own abilities, they need to ask and be asked the appropriate questions, which is similar to the active learning strategy, Socrates Questioning, which will be discussed later. This approach gives the chance to all students to reflect and be encouraged to say out their answers because the instructor listens to all the answers without judgment, which keeps students thinking till they find solutions to the problems at hand (Türkçapar, Kahraman \& Sargýn, 2015).

In previous studies the results indicate that the problems in the problem-solving performance of bilingual students are not only limited to those related to difficulties in understanding word problems in their less proficient language, the problems also might be associated with learning experiences that give rise to the acquisition of problematic strategies (Durkin \& Shire, 1991; Verschaffel, Greer \& De Corte. 2000; Abedi \& Lord, 2001; Musanti, Celedón-Pattichis \& Marshall, 2009; Bernardo \& Calleja, 2005; Wolf \& Leon,2009; Beal, 
Adams \& Cohen ,2010; Linquanti \& Cook, 2013; and Al Masri (2013), Driver \& Powell 2017; Dokter, Aarts, Kurvers, Ros \& Kroon ,2017). On the other hand, Crockett (2002) and Musanti, Celedón-Pattichis \& Marshall (2009) found that ongoing reflection, collegial conversations, and analysis of students' work contributed to enhancing teacher's understandings of students' mathematical learning, and of practices that provided students opportunities to solve contextualized mathematics problems, to communicate their solutions, and to represent their thinking. It was also found that AL strategies improve students' reading, writing, speaking and listening skills (Al-Amery, 2020).

If mathematics educators use word problems to allow students to explore the application of mathematical concepts and procedures to various domains, there needs to be a reexamination of the manner in which these types of mathematical tasks are used in the classroom. This understanding should "guide the development of alternative pedagogies for developing useful and applicable mathematical knowledge among students" (Bernardo \& Calleja, 2005- p126). For example, Hairol, Mohammad \& Shahrill (2014) proved that students did not require good English to do Mathematics word problems questions with less than 40 words, yet they needed strategies in order to help them solve problems.

These findings align with the researcher's aim to try other strategies in teaching mathematics, such as ALS, to improve students' performance in solving mathematical problems. Therefore, with this in mind, it can be concluded that a good mathematics foundation is necessary in order to perform well in mathematics word problems.

2.1.1 Problem Solving. Solving mathematical problems is at the heart of mathematics education, and mathematics educators have articulated a vision for teaching mathematics that includes engaging students in problem-solving, mathematical argumentation, and reflective communication (NCTM, 1991). Three types of approaches are identified to teach problem-solving. The first approach (teaching for problem-solving). turns students into passive listeners who are well-practiced only in using formulas that they do not understand (Cunningham, 2004), the second approach (teaching about problem-solving) involves teaching students how to problem solve, which can include teaching the process or strategies for solving a problem through real contexts, problems, situations, and models, so they can move to abstract concepts (Polya, 1973; Schroeder and Lester,1989; Felmer, Pehkonen \& Kilpatrick ,2016; Lee, 2017). The third approach, (teaching through problemsolving), is at the core of IBL with the problem presented at the beginning of a lesson and skills emerging from working with the problem (Schroeder and Lester, 1989). This approach takes students' differences into consideration and is the basis of AL.

2.1.2 Active Learning Strategies. Are strategies that allow students to learn and see the usefulness of what they learn, connects it to the real world, and interacts with others. They include co-operative activity, collaborative problem-solving and sharing. In this study, the researcher will rely on three ALS due to their practicality and easy implementation by teachers in all school settings, They are Inquiry Based Learning (IBL), Think/Pair/Share (TPS), Socratic Questioning (SQ).

2.1.2.1 Inquiry Based Learning (IBL). It derives from the Problem Based Learning (PBL) model (Feletti, 1993). The roots of inquiry-based education can be found in recognizing the importance of children having an active role in their learning in the writings of educators such as Homer Lane (1875-1925), Dewey (1870-1952) and Montessori (1870-1952), drawing on the earlier ideas of Rousseau (1712-1778), Pestalozzi (1746-1827), and Froebel (1782- 1852 "Students cannot learn in school everything they will need to know in adult life. Students must become able to organize and regulate their own learning, to learn independently and in groups, and to overcome difficulties in the learning process. This requires them to be aware of their own thinking processes and learning strategies and methods" (OECD, 2000, p. 90).

Studies on the effect of IBL on students' performance in PS showed that IBL improves students' problemsolving skills because it increases students' motivation and engagement in mathematics; it also helps them develop mathematical and scientific curiosity and creativity as well as their potential for creative thinking, critical reflection, reasoning and analysis, and their autonomy as learners (Jonassen, 2011; Harlen, 2013; Fielding-Wells, O’Brien, \& Makar ,2017; Khoiriyah, \& Husamah, 2018). Moreover, Nahas (2008) believes that an early implementation of PBL is better for the student's cognitive development.

2.1.2.2 Socratic Questioning. The Socratic method of questioning is a focused, structured style of questioning aimed at generating a dialogue in order to deepen learning and sharpen thinking (Burger \& Starbird, 2012, p. 73). Socratic Questioning (SQ) has its roots in a style of discourse originating with ancient Greek philosopher Socrates (470-399 BC) who taught his followers by asking questions; these conversations between them are known as "Socratic dialogues" (Türkçapar, Kahraman \& Sargýn, 2015) ..

In describing Socratic education, Woodruff (1989) affirms that "nothing is more important to this kind of education than the resources that learners bring to it" ( $p$ 14). It encourages students to process and critically think about the productive use of information and come to their own conclusions (Hunkins, 1989 - p 4). This metacognitive activity "enables students to be autonomous learners, empowering them to control their learning" (Hunkins, 1989- p19). 
Studies on the effectiveness of SQ affirmed that the use of Socratic questioning, reasoning, and dialogue encourage critical thinking, problem-solving, and independent learning (Leszczyńska-Jasion, Urbański \& Wiśniewski, 2013; Wilberding ,2019). Teachers using Socratic questions can provide differentiated instruction to their students. (Egg Harbor Township Schools, 2008), and they must remain fully attentive to students' responses in order to determine where to take the dialogue next and authentically meet students "where they are" intellectually. "(Barnes \& Payette, 2017-p9).

Beside its effectiveness, the choice fell on SQ because teachers can use it in any classroom setting and regardless of the number of students in class. The third strategy that will be adopted in this study is Think -PairShare (TPS).

2.1.2.3 Think/ Pair /Share. (TPS) is a cooperative discussion strategy that was first developed by Professor Frank Lyman and his colleagues at the University of Maryland in 1981. It has been adopted by many educators in the field of cooperative learning since then. It gets its name from the three phases of student action, with an emphasis on what students are to be doing in each of those phases (Marzano \& Pickering, 2005). The three phases are: (a) Think: the teacher provokes students' thinking with a question, prompt, or observation. The students should take a few minutes just to "Think" about the question. This is a self -reflective stage where learners develop personal meanings in what Vygotsky (1978) called the intrapsychological stage. During this stage the think- wait-time period of uninterrupted silence, students could complete appropriate information processing tasks, solving word problem and reflective thinking. (b) Pair: with a partner or a desk-mate, students "pair" up to talk about the answer each has come up with. They compare their mental or written notes and identify the answers they think are best or most convincing. (c) Share: after students talk in pairs for a few minutes, the teacher calls for pairs to "share" their thinking with the rest of the class (Roberston, 2006).

According to Robertson (2006), TPS benefits students in the areas of peer acceptance, peer support, academic achievement, self-esteem, and increased interest in learning. Moreover, Nancy K Schoolcraft (2015) found that students who struggled with language comprehension or vocabulary found additional quiet time useful when they knew they would be required to explain thinking to the class.

Most of the studies about the use of ALS in general and TPS strategy in particular identified their impact on the academic achievement. Most of them used the experimental approach and the major common findings that connected between the previous studies are that ALS strategy have a role in raising academic achievement and the development of various types of thinking skills, and the reduction of math anxiety among students (Al-Alloul, 2012; Zoubi, 2014; Farajallah, 2017).

This study was based on previous studies by Al-Alloul (2012), Schoolcraft (2015) and Farajallah (2017) who studied the effects of using active learning strategies on students' performance in PS. Schoolcraft (2015) studied the effects of using the active learning strategy Think Pair Think Share (TPTS) on high school learners who struggle with academic language in geometry classrooms. Al-Alloul (2012) studied the effect of three active learning strategies: educational theater, cooperative learning, and learning by playing on Grade 4; she found significant statistical differences between pre and post-mathematical problem-solving tests for the experimental group. However, Farrajallah (2107) studied the effects of using the active learning strategy (TPS) in teaching mathematical problem-solving on Grade 5. Farrajallah (2107) found significant statistical differences between the mean scores of the experimental group and control group in the post-test of mathematical communication skills; these differences were also in favor of the experimental group.

Both Schoolcraft (2015) and Farrajallah (2107) assumed that ALS create a healthy and vibrant environment, which brings joy to the study of mathematics. They also provide students an opportunity to ask questions, discuss and exchange ideas, give and receive assistance, explore situations, search for patterns and relationships in the collection of data and to freely formulate and choose assumptions. Discussing mathematical tasks with peers increased their understanding above teacher lecture alone.

To conclude, the current study involved examining the following hypothesis which was derived from the previous relevant research findings presented above. Accordingly, the study predicted that Cycle Two students would score higher in PS after being taught through ALS in comparison to Cycle Two students who would receive the traditional instructions.

\section{Purpose of the Study}

This article reported on a part of a larger mixed-methods, quasi-experimental study designed to investigate the impact of implementing a training program on the use of active learning strategies based on specific techniques mainly Think Pair Share, Socratic Questioning, and Inquiry-Based-Learning on students' performance in "problem- solving". Thus the current study addressed the following question:

1- To what extent do students benefit from classes taught with active learning strategies in problem solving compared to those who are taught in a traditional way? 


\section{Methodology}

This section of the article describes the methodology used in carrying out this part of the original study.

\subsection{Research Design}

The part of the study reported in this article adopted the quasi-experimental pre-test /post-test design to investigate the effect of using ALS (independent variable) on students' performance in PS (dependent variable) on Cycle two students in three Lebanese private schools

\subsection{Population and Sample.}

The study was conducted in three private schools in North of Lebanon (School A, B and C). The three schools were chosen to participate in the study according to the following specific criteria:(a) were private, (b) had more than six hundred students (c) served students middle and upper- middle classes, (d) used English in teaching mathematics, (e) instructed both genders in same classroom, (d) had different teachers to teach Grade 6 . The purpose was also to identify to whom the study findings might generalize (Graham \& Harris, 2014).

All intact sections of Grade 4 and Grade 5 were assigned to the experimental group; and all intact sections of Grade Six were assigned to the control group because Grade 6 teachers did not teach Grade 4 and Grade 5 in those schools.

The sample size for the present study consisted of 454 Cycle Two students (G4-G5-G6) along with their 8 teachers. There were 315 students in the experimental classes (16 sections) and 113 students in the control classes ( 5 sections). Prior to the intervention, the authors of the present study presented questionnaires to the teachers and found out that teachers at the three schools were comparable in terms of working experience. Teachers responses revealed that all teachers demonstrated awareness of their students' difficulties in PS, and they all expressed the need to learn new strategies to teach PS. All teachers' and students' names were coded to maintain confidentiality.

\subsection{Teacher Training}

Teachers in the experimental group received a full day training about implementing active learning strategies in general, and Think /Pair/Share (TPS), Socratic questioning (SQ), and Inquiry Based Learning (IBL) in particular. The training was executed in collaboration with the University of Saint Joseph-Beirut (USJ).

\subsection{Instruments}

To answer the research question, pre- and post- tests were designed in collaboration with the school coordinators and administered before and after implementing ALS to compare students' achievement in problem-solving. All instruments were pilot-tested before the commencement of the study.

\subsection{Data Collection Procedures.}

Students in the experimental and control groups completed a pre-test one month before the ALS intervention and a post-test after three months of the intervention. Moreover, students and teachers in the experimental group answered pre- and post-questionnaires to assess the validity of the ALS used.

\subsection{Data Analysis Procedures}

To reduce the threat to validity, descriptive and inferential statistics were used to make sure that the two groups were statistically equal as recommended by Mills and Gay (2016, p- 307). An advantage of the non-equivalent control group design is that possible effects from reactive arrangements were minimized because established classes were selected. The descriptive and inferential statistics included reporting and comparing the pre-test and post-test mean scores as well as the T-tests of the experimental and control groups on PS. The dependent and independent-samples T-tests were used to measure the difference between the mean scores of the experimental and control groups at the pre-test and post-test level. The effect size was calculated for the independent samples.

\subsection{Treatment Fidelity}

The researcher tried to determine if teachers in the experimental group implemented ALS in their teaching practices (Smith et al., 2007). For this reason, the researcher with the schools coordinators made pre- and postclass observations and used an observation checklist adapted from Moukarzel (2013) to verify and evaluate the use of ALS in classes before and after teachers' training in order to better understand the nature of teaching practice, and to make sure that all teachers in the experimental group implemented IBL, SQ and TPS properly.

\subsection{Control Group}

During the duration of the study, the researcher also made pre- and post -class observations to make sure teachers in the control group kept using their same instructional methods. 


\section{Results}

In this study the independent groups were the experimental group which had $321 \mathrm{Grade} 4$ and Grade 5 students from Schools A, B, and C, and the control group which consisted of 133 Grade 6 students of the same schools. the Statistical Package for Social Sciences (SPSS) was used to perform the required analysis. The researcher used the independent t-test to compare post grades between the experimental and control groups, and the dependent t-test or paired t-test to compare the means within each of the experimental and control groups for Cycle Two students in schools A, B, and C.

Thus, the researcher was looking to see if the alternative hypothesis $\mathrm{H}_{1}$ : "Students who are taught Mathematics through active learning strategies will get higher scores on problem-solving than their counterpart who are taught math in the traditional way" can be supported. The independent variable was defined as the use of ALS in solving mathematics problems in class. The dependent variable was identified as students' scores in PS, and two sub-hypotheses were derived from $\mathrm{H}_{1}: \mathrm{H}_{1}$ ': There is no significant difference between the mean scores of the students in the experimental and control groups on the pre- mathematics test. $\mathrm{H}_{1}$ ": There is a significant difference in the Mathematics mean scores of the students in the experimental group before and after implementing ALS.

\subsection{Verifying $\mathrm{H}_{1}$.}

The aim of the first sub-hypothesis was to check if these two unrelated groups of students (control and experimental) were matching at the commencement of the experiment to have control over any possible alternative explanation of the research results as suggested by Cohen (2018) and Creswell (2012). Therefore, the researcher compared the students' pretest mean scores of the two groups at the pre-level i.e. before the intervention. With $n=315$ for the experimental group (six students were absent during the pretest) and $n=133$ for the control group, (Table 1) showed that the averages of the two groups were similar: the means of the experimental and control groups on the mathematics pretest were 3.52 and 3.40 respectively.

Table 1: Pre- level /Independent T-test for equality of means for the experimental and control groups

\begin{tabular}{lllll}
\hline & $\mathrm{N}$ & Mean & Std. Deviation & Std. Error Mean \\
\hline Experimental & 315 & 3.5278 & 2.77791 & .15652 \\
Control & 133 & 3.4079 & 2.21788 & .19231 \\
\hline
\end{tabular}

To read the $\mathrm{P}$ value (Table 2), we followed the second row because equal variances was not assumed. Equal variances across samples is called homogeneity of variance, and Levene's test (Levene, 1960) is used to test if samples have equal variances. According to Parra-frutos (2009), when the sample size is big (sample size $>30$ ), as is the case in this study, then the t-test is robust to violations of homogeneity of variance; this is the reason we read the data on the second row as: $\mathrm{t}=0.483$, df $307.976, \mathrm{P}=0.629>0.05$.

Table 2... Pre/Independent T-test for Equality of Means for the experimental and control groups Levene's Test for Equality of Variances t-test for Equality of Means

95\% Confidence Interval of the

Equal F $\quad$ Sig. $\quad$ T $\quad$ d assumed

Equal

442446

Sig.

orDifference

(2tailed)DifferencDifference Lower Upper

$659 \quad 11988$

.65329

assumed

With P-value $=0.629>0.05$ (Table 2 ) we concluded that the two groups (experimental versus control) were equivalent at time zero (pre intervention); therefore the sub-hypothesis $\mathrm{H}_{1}$ ' was verified. Having the two independent groups, control and experimental, statistically similar at the commencement of the experiment was a necessary condition to maintain the internal validity of the intervention (Cohen, 2018, p-404; Creswell, 2012, p309).

\subsection{Verifying $\mathrm{H}_{1}$ "}

In addition to the independent t-test, the researcher wanted to also verify if there was a significant difference in students' scores in the experimental group before and after implementing ALS; hence, testing the second subhypothesis $\mathrm{H}_{1}$ ": There is a significant difference in the mathematics mean scores of the students in the experimental group before and after implementing ALS.

The major advantage of choosing a repeated-measures design (and therefore, running a dependent t-test) is that it helps to eliminate the individual differences that occur between participants which increases the power of the test (Parra-Frutos, 2009). For this reason, the researcher had to eliminate the students who sat for either the pretest or the post-test as well as the outliers. There were only 269 students (Table 3 ) in the experimental group 
who sat for both tests because some of them were absent either during the pretest or during the post-test.

Table 3 Dependent T-test pre- post level for experimental group

\begin{tabular}{lllll}
\hline & Mean & $\mathrm{N}$ & Std. Deviation & Std. Error Mean \\
\hline Pre & 3.4405 & 269 & 2.75892 & .16821 \\
Post & 4.2257 & 269 & 2.97067 & .18113 \\
\hline
\end{tabular}

Based on the p-value $(<0.001)$ (Table 4$)$ there was a significant difference between the two means. The Post mean was equal to 4.225 versus the Pre mean equal to 3.440 . Hence, we accepted the second sub-hypothesis: $\mathrm{H}_{2}$ ": There is a significant difference in the mathematics mean scores of the students in the experimental group before and after implementing ALS.

Table 4 Pre/post Dependent t-test for experimental groups

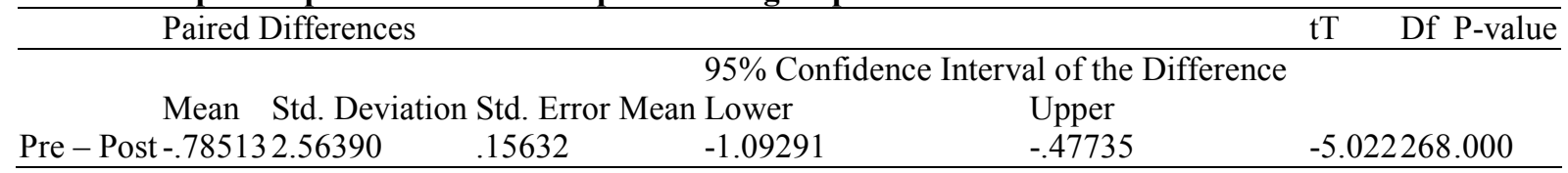

\subsection{Verifying $\mathrm{H}_{1}$}

To verify $\mathrm{H}_{1}$, the researcher used independent T-test to compare the students' mean scores on the mathematics post-test, at the post- level or after the intervention, for the control and experimental groups (Table 5) and (Table $6)$.

Table 5 Post- level / Independent t-test for equality of means for the experimental and control groups

\begin{tabular}{lllll}
\hline & $\mathrm{N}$ & Mean & Std. Deviation & Std. Error Mean \\
\hline Experimental & 291 & 4.1577 & 2.91368 & .17080 \\
Control & 116 & 3.4397 & 2.56473 & .23813 \\
\hline
\end{tabular}

With $n=291$ in the experimental group and $n=116$ in the control group, Table 5 showed that the mean of the experimental group on the mathematics post-test was 4.15 versus mean equals 3.43 for the control group.

With P-value $=0.015<0.05$ (Table 6) we conclude that there is a significant difference between the two means. Hence, we accept the alternative hypothesis $\mathrm{H}_{2}$ : Students who are taught Mathematics through active learning strategies will get higher scores on problem-solving than their counterpart who are taught math in the traditional way. The results showed that although the experimental and control groups had no significant difference in their mean scores at the pre-test level $\mathrm{P}=0.62>0.05$, there was a significant difference in their mean score at the post level with $\mathrm{P}=0.15<0.05$. Students in the experimental group achieved better in PS than their counterparts in the control group after using ALS.

Table 6 Post/Independent T-test for Equality of Means for the experimental and control groups. Levene's Test for Equality of Variances t-test for Equality of Means $95 \%$ Confidence Interval

Mean Std. Errorof the Difference

\begin{tabular}{cccccccccc} 
& $\mathrm{F}$ & Sig. & $\mathrm{T}$ & $\mathrm{Df}$ & \multicolumn{2}{l}{-value } & \multicolumn{2}{c}{ Difference Difference Lower } & Upper \\
Equal & variances6.128 & .014 & 2.320 & 405 & .021 & .71808 & .30954 & .10957 & 1.32658
\end{tabular}
assumed

Equal.variances.not

$\begin{array}{lllll}2.450 & 238.713 .015 \quad .71808 \quad .29305 \quad .14078\end{array}$

1.29537

assumed

\subsection{Effect Size}

Many researchers such as Coe (2000), Finch, Cumming, \& Thomason (2001), Wright (2003), Creswell (2012), and Cohen (2018) believe that a yes/no hypothesis testing answer to quantitative questions and hypotheses leads to misinterpretations of results. It is not enough to know whether the statistical test was significant through $p$ values, but researchers need "to quantify the strength of the difference between two means or two variables" (Creswell, 2012; p-195). With coefficient of Cohen's $d=0.26$, the correlation is modest as classified in Cohen (2018, p-746). This is due to the fact that both groups, control and experimental, had mean scores below the average on a 10 point-quiz and to the short period of time of the study.

\section{Discussion and Interpretation}

As stated earlier, the results reported in this article were part of a larger mixed-methods, quasi-experimental study, and they were related to the research question which investigated the effect of using ALS on students' performance in PS. This section discusses these results, relates them to earlier relevant research and theories in the field, and provides some interpretations.

The results showed that Cycle Two students who were taught through active learning strategies got higher scores on problem-solving than their counterpart who were taught mathematics in the traditional way. Although 
the effect size showed a modest correlation, Cohen's $d=0.26$, this could be due to the short period of time of the study.

This result was also expressed by $100 \%$ of the teachers, in the post questionnaire, who affirmed, after the intervention, that some students improved in problem-solving after increasing the use of SQ and TPS; and the areas of improvement were mainly in students' ability to analyze and build on previous knowledge. Thus, the intervention improved students' beliefs in their capabilities to solve problems, and this improvement was interpreted by improvement in their mean scores at the post-test level. Moreover, the teachers who expressed the need to learn new strategies to teach problem-solving, were able to do so by the use of TPS, SQ, and IBL as justified by the experimental group students' performance in the post-test.

Moreover the difference in performance between the control and experimental groups means that the improvement was not due to maturity, but was due to the intervention. Therefore the intervention that was based on the use of three active learning strategies

TPS, SQ and IBL had a positive impact on the students' performance in problem-solving as confirmed in previous studies (Lutfullah, 2005; Kaddoura, 2006 ; Ngozi, 2009; Al-Alloul, 2012; Basri et al. 2013; Al-Masri, 2013; Zoubi, 2014; Schoolcraft, 2015; Mikati, 2017; Farajallah; 2017). The use of active learning strategies such as TPS, SQ and IBL provided students with "think" time to reflect on the given problem before they got engaged in dialogues in order to deepen their understanding. Giving students an opportunity to think could enhance their metacognitive skills which are essential for developing their abilities to problem solve Those strategies provided activities that promoted students' metacognitive skills through guided questioning, and increased their engagement in mathematics. According to Harlen (2013), IBL helps students develop mathematical and scientific curiosity and creativity as well as their potential for critical reflection, reasoning and analysis, and their autonomy as learners.

Interestingly, the findings of this study match with the findings of previous studies (Lutfullah, 2005; Kaddoura, 2006; Ngozi, 2009; Al-Alloul, 2012; Basri et al. 2013; Al-Masri, 2013; Zoubi, 2014; Schoolcraft, 2015; Mikati, 2017; Farajallah; 2017) about the effect of using active learning strategies in mathematics, science and nursing classes across different grade levels, and showed significant difference in students' performance even with the visually impaired Grade Four students in Lutfullah study (Lutfullah, 2005).

Furthermore, studies done on the relationship between language and problem-solving suggested that the relationship of English-reading skill and math performance require a minimum reading level associated with improvement in math performance (Abedi \& Lord, 2001 and Wolf \& Leon, 2009). Moreover, Crockett (2002) and Musanti, Celedón-Pattichis \& Marshall (2009) show that ongoing reflection, conversations, and analysis of students' work contribute to enhancing teacher's understandings of students' mathematical learning, and provide students opportunities to solve contextualized mathematics problems, to communicate their solutions, and to represent their thinking.

Moreover, previous studies about the use of Think-Pair-Share show improvement in students' fluency with mathematics vocabulary, increase in variation of solutions; increase in students' discourse during problemsolving, and a more positive teachers' views about the effectiveness of cooperative learning (Lutfullah, 2005; Kaddoura, 2006; Ngozi, 2009;; Al-Alloul, 2012; Schoolcraft, 2015). When students are given time to think alone, and then share their thinking with others, they experience the processes of assimilation and accommodation, or reflective thinking as Piaget refers to it, at their own pace. The teacher should not step in and show how to solve a problem as soon as a student pauses because it does not help the student learn mathematics. Students need to engage in productive struggle to learn mathematics. Piaget postulates that learners are going to experience disequilibrium in developing new ideas, and students should know that this disequilibrium is part of the process (Hiebert \& Grouws, 2007).

At the theoretical level, findings from analyzing the research question reported in this paper supported the theoretical framework stated earlier as well. Firstly, they supported constructivism and social constructivism as reflected in Piaget's and Vygotsky's views about the importance of giving the students active role in constructing their learning as well as the importance of the social element in students learning as emphasized by Vygotsky and Bronfenbrenner. These findings also reflect the andragogy theory as manifested in the importance of teachers' PD which help to create classroom environments that promote students learning and understanding.

\section{Limitations}

The limitations of a study are boundaries that the researcher cannot control (Perry,1998). The limitation was due to the selection of private schools that used English as the means of instruction and had more than 600 students in order to have enough teachers to be assigned into control and experimental group. In that regards, the findings of this study could be generalized to schools that have the same characteristics of the schools included in this study. 


\section{Implications for Practice}

Based on the positive effect of the intervention, it is recommended to use active learning strategies in teaching problem solving. The use of such strategies gave the students the chance to take an active role in their learning; it also increased their understanding of the problems they solved, their ability to interpret results, their self-efficacy and their achievement in problem-solving as well.

\section{Conclusion and Recommendation for Future Research.}

This study was a pioneer in investigating the effects of using active learning strategies on students' achievement in problem-solving in Cycle Two not only in Lebanon, but also in the educational literature, to the knowledge of the researcher. And in spite of the short period of the study, the results showed significant difference in students' achievement in problem-solving between the control and experimental group in favor of the experimental group.

First, it is recommended to conduct this research on another sample representative of the population, i.e. a sample which includes different private schools taken from different geographical areas. And then on a larger scale which includes private and public schools, where the language of instruction is Arabic, English or French in order to test and compare other factors that might affect students' achievement in problem solving.

Second, it is recommended to conduct case studies in various schools to be able to make interviews with students and probe their difficulties in problem-solving, and the effect of using ALS on their achievement in PS over a period of time.

Third, it is recommended to conduct this research over a whole academic year, so teachers could have time to implement IBL without being overstressed with curriculum constraints.

\section{References}

Abedi, J., \& Lord, C. (2001). The language factor in mathematics tests. Applied Measurement in Education, 14, 219-234. doi:10.1207/S15324818AME1403 2.

Al-Aloul, R.(2012). The effect of using some of active learning strategies for developing mathematical solving problem skills for the Fourth-Grade students in Gaza Governorate [master's thesis, Al-Azhar UniversityGaza]. http://search.shamaa.org/FullRecord?ID=75757

Al-Amery, A. (2020). Attitudes of the Students at the Institutes of Fine Arts in Iraq Towards Implementing Active Learning Strategies in Arabic Language Courses and the Associated Challenges Journal of Education and Practice, 11(13), 73-81. Doi: 10.7176/JEP/11-13-08.

Al Masri, H. M. (2013). Difficulties of construction and formulating geometric proofs by Lebanese middle school students learning math in English [master's thesis. Lebanese American University]. doi: https://doi.org/10.26756/th.2013.19

Barnes, B., \& Payette, P. (2017). Socratic questioning. The National Teaching \& Learning Forum, $26(6), 6-8$. doi:10.1002/ntlf.30129.

Basri, Sahar, Abdul Wahid Kan'any, and Hassam Kanani. (2013). Strategies of Guided discovery and its impact on the mathemtical communication skills. Educational and psychological research journal -Iraq. p. 36, pp. 269-288

Beal, C. R., Adams, N. M., \& Cohen, P. R. (2010). Reading proficiency and mathematics problem solving by high school English language learners. Urban Education, 45(1), 58-74. doi:10.1177/0042085909352143.

Bernardo, A. B. I., \& Calleja, M. O. (2005). The effects of stating problems in bilingual students' first and second languages on solving mathematical word problems. The Journal of Genetic Psychology, 166(1), 117-129. doi:10.3200/GNTP.166.1.117-129.

Bransford, J., Brown, A. and Cocking, R. (2000). How People Learn. Washington, DC: National Academy Press.

Bronfenbrenner, U. (1979;1981;). The ecology of human development: Experiments by nature and design. Cambridge, Mass: Harvard University Press.

Bronfenbrenner, U. (2004). Making human beings human: bioecological perspectives on human development. Thousand Oaks: Sage Publications.

Brown, A. L. (1987). Metacognition, executive control, self-regulation, and other more mysterious mechanisms. In F. E. Weinert \& R. H. Kluwe (Eds.), Metacognition, motivation, and understanding (pp. 65-116). Hillsdale, NJ:Lawrence Erlbaum Associates.

Bruner, J. and Haste, H. (1987). Making sense: the child's construction of the world. London, New York: Methuen.

Burger, E \& Starbid, M. (2012). The 5 elements of effective thinking. Princeton University Press. doi: $10.2307 /$ j.ctv6zdbhm.

Callingham, R., Beswick, K., \& Ferme, E. (2015). An initial exploration of teachers' numeracy in the context of professional capital. ZDM Mathematics Education,47(4), 549-560.

Campione, J. C., Brown, A. L, \& Connell, M. L. (1989). Metacognition: On the importance of understanding what you are doing. In R. I. Charles \& E. A. Silver (Eds.) Teaching and assessing mathematical problem 
solving (pp. 93-114) of Teachers of Mathematics.

Claxton, G. (2008). What's the point of school? rediscovering the heart of education, Oxford: One-world Publications.

Cohen, L., Manion, L., \& Morrison, Keith (Keith R. B.). (2018). Research methods in education (8th ed.). London: Routledge. doi:10.4324/9780203720967.

CRDP (Center of Educational Research and Development) (2019). Curricula. http://www.crdp.org/newsdetails/26465/ar/

CRDP (Center of Educational Research and Development) (2020). Mathematics curriculum objectives. http://www.crdp.org/curr-content-desc?id=

Creswell, J. W. (2012). Educational research. Planning, conducting, and evaluating quantitative and qualitative (4th ed.). Pearson Education Inc. http://www.academia.edu/download/31060487/MCTE690-syllabussummer2003.pdf.

Crockett, M. D. (2002). Inquiry as professional development: Creating dilemmas through teachers' work. Teaching and Teacher Education, 18(5), 609-624. doi:10.1016/S0742-051X(02)00019-7

Coe, R., Fitz-Gibbon, C. T. and Tymms, P. (2000, September) Promoting evidence-based education: the role of practitioners. Roundtable paper presented at the British Educational Research Association, University of Cardiff, http://www.leeds.ac.uk/educol/documents/00001592.htm

Curriculum Document (1997). Defining pre-college curricula and objectives The Official Newspaper, 1, 228-289.

Cunningham, R. F. (2004). Problem posing: an opportunity for increasing student responsibility. Mathematics and Computer Education, 38, 83-89.

Dokter, N., Aarts, R., Kurvers, J., Ros, A., \& Kroon, S. (2017). Academic language in elementary school mathematics: Academicness of teacher input during whole class instruction. Dutch Journal of Applied Linguistics, 6(2), 213-230. doi:10.1075/dujal.17007.dok.

Driver, M. K., \& Powell, S. R. (2017). Culturally and linguistically responsive schema intervention: Improving word problem solving for English language learners with mathematics difficulty. Learning Disability Quarterly, 40(1), 41-53. doi:10.1177/0731948716646730.

Durkin, K., \& Shire. B.(1991). Language in mathematical education: Research and practice. Buckingham. England: Open University Press.

Duval, S., \& Wicklund, R. A. (1972). A Theory of Objective Self Awareness. New York: Academic Press.

Egg Harbor Township Schools, 2008. Differentiated instruction - Socratic questions. Accessed at http://www.eht.k12.nj.us/ Jonesj/Differentiated\%20Instruction/Socratic\%20Questions.

Eggen, P., \& Kauchak, D. (2013). Educational psychology: Windows on classrooms $\left(9^{\text {th }}\right.$ ed.). Columbus, OH: Pearson Education.

Farajallah, A (2017). The impact of employing the (think -pair -share) strategy to gain some number sense skills and mathematical communication skills among fifth grade students. An-Najah University Journal for Research - Humanities, 31(9), 1627-1663.

Feletti, G. (1993). Inquiry based and problem based learning: How similar are these approaches to nursing and medical education? Higher Education Research and Development, 12(2), 143-156. doi:10.1080/0729436930120203

Felmer, P., Pehkonen, E., \& Kilpatrick, J.(2016). Posing and Solving Mathematical Problems: Advances and New Perspectives. Cham: Springer International Publishing. doi:10.1007/978-3-319-28023-3

Fielding-Wells, J., O’Brien, M., \& Makar, K. (2017). Using expectancy-value theory to explore aspects of motivation and engagement in inquiry-based learning in primary mathematics. Mathematics Education Research Journal, 29(2), 237-254. doi:10.1007/s13394-017-0201-y

Finch, S., Cumming, G., \& Thomason, N. (2001). Reporting of statistical inference in the journal of applied psychology: Little evidence of reform. Educational and Psychological Measurement, 61(2), 181-210. doi:10.1177/00131640121971167

Fisher, J. (2002) Starting from the Child, Buckingham: Open University Press.

Forman, E. A., \& McPhail, J. (1993). A Vygotskian perspective on children's collaborative problem solving activities In E. A. Forman, N. Minick, \& C. A. Stone (Eds.), Contexts for learning: Sociocultural dynamics in children's development (pp. 213-229). New York, NY: Oxford University Press.Fosnot, C. T.

Garofalo, J., \& Lester, F. K. (1985). Metacognition, cognitive monitoring, and mathematical performance. Journal for Research in Mathematics Education, 16(3), 163- 176. doi:10.2307/748391

Graham, S. \& Harris, K. R. (2014). Conducting high quality writing intervention research: Twelve recommendations. Journal of Writing Research, 6(2), https://www.jowr.org/Ccount/click.php?id=85

Hairol Azaman Hj Pungut, Hj Mohammad, \& Shahrill, M. (2014). Students English language abilities in solving mathematics word problems. Mathematics Education Trends and Research, 2014, 1-11. doi:10.5899/2014/metr-00048. 
Harmouch, T., Khraibani, Z. \& Atrissi, T. (2017). A Multilevel Analysis to Analyse The Timss Data: A Comparison of The Lebanese And Singapore. International Journal of New Technology and Research (IJNTR), 9 (3), 87-102. https://www.neliti.com/publications/263232/a-multilevel-analysis-to-analyse-thetimssdata-a-comparison-of-the-lebanese-and\#cite

Harlen, W.(2013). Inquiry-based learning in science and mathematics. Review of Science, Mathematics And IctEducation, 7(2),9-33.Retrievedfrom:

https://www.google.com.lb/search?q=Harlen\%2C+W.(2013).+Inquirybased+learning + in + science + and + mat hematics

Hart, S., Dixon, A., Drummond, M.J. and McIntyre, D. (2004). Learning without Limits. Maidenhead: Open University Press.

Hiebert, J., \& Grouws, D. A. (2007). The effects of classroom mathematics teaching on students' learning. In F. K. Lester \& National Council of Teachers of Mathematics. (Ed.), Second handbook of research on mathematics teaching and learning (pp. 371-404). Charlotte, NC: Information Age Publishing.

Hunkins, F. P.(1989). Teaching thinking through effective questioning. Christopher-Gordon Publishing, Inc.

Jonassen, D. (2011). Supporting problem solving in PBL. Interdisciplinary Journal of Problem-Based Learning, 5(2) doi:10.7771/1541-5015.1256

Kaddoura, M. (2013). Think pair share: A teaching learning strategy to enhance students' critical thinking. Educational Research Quarterly, 36(4), 3.

Kearsley, G. (1993). Hypertext as a tool for the metatheoretical analysis of learning theories: The TIP database. Journal of Computing in Higher Education, 4(2), 43-56. doi:10.1007/BF02941064

Khoiriyah, A. J., \& Husamah, H. (2018). Problem-based learning: Creative thinking skills, problem-solving skills, and learning outcome of seventh grade students. JPBI (Jurnal Pendidikan Biologi Indonesia), 4(2), 151-160. doi:10.22219/jpbi.v4i2.5804

Kilpatrick, J. (1985). Reflection and recursion. Educational Studies in Mathematics, 16(1), 1-26. doi:10.1007/BF00354880

Lee, C. I. (2017). An appropriate prompts system based on the polya method for mathematical problem-solving. Eurasia Journal of Mathematics, Science and Technology Education, 13(3), 893-910. doi:10.12973/eurasia.2017.00649a.

Levene, H. (1960). In Contributions to Probability and Statistics: Essays in Honor of Harold Hotelling, I. Olkin et al. eds., Stanford University Press, pp. 278-292.

Leszczyńska-Jasion, D., Urbański, M., \& Wiśniewski, A. (2013). Socratic trees. Studia Logica, 101(5), 959-986. doi:10.1007/s11225-012-9404-0

Linquanti, R., \& Cook, H. G. (2013). Toward a "common definition of English learner": A brief defining policy and technical issues and opportunities for state assessment consortia. CCSCO: Council of Chief State School Officers. Washington, DC

Lutfallah, N. (2005). The effect of using TPS strategy on academic achievement and innovative thinking and achievement motivation among visually impaired fourth grade students. Egypt Journal of Science Education, vol 8, p 3, pp. 113-162

Marshall, C., \& Rossman, G. B. (2006). Designing qualitative research (4th ed.). Thousand Oaks, CA: Sage.

Marzano, R.J., \& Pickering, D.J.(2005). Building academic vocabulary: Teacher's manual. Alexandria, VA: Association for Supervision and Curriculum Development.

Mikati, H. \& Moucharafieh, J (2017). Performance on mathematics word problems as related to English language proficiency and problem format: A correlational study in two private schools in northern Lebanon [mater's thesis, University of Balamand]. retrieved from: search.shamaa.org

Mills, G. E., \& Gay, L. R. (2016) Education research: Competencies for analysis and applications. 12th edition. London, England: Pearson Education.

Monk, J., \& Silman, C. (2013;2014;). Active learning in primary classrooms: A case study approach. New York;London;: Routledge. doi:10.4324/9781315833484

Moukarzel, D. M (2011). La formation continue des enseignants des écoles indépendantes au Qatar - Étude de cas [Doctoral dissertation, Universite Mulhouse Colmar De Haute Alsace]. https://tel.archivesouvertes.fr/tel-00666113/document

Murnane, R. J., Willett, J. B., Braatz, M. J., \& Duhaldeborde, Y. (2001). Do different dimensions of male high school students'skills predict labor market success a decade later? Evidence from the NLSY. Economics of Education Review,20, 311-320. doi:10.1016/s0272-7757(00)00056-x.

Musanti, S. I., Celedón-Pattichis, S., \& Marshall, M. E. (2009). Reflections on language and mathematics problem solving: A case study of a bilingual first-grade teacher. Bilingual Research Journal, 32(1), 25-41. doi:10.1080/15235880902965763

Nahas, G. (2008). PBL and concept acquisition. Research Symposium on PBL \& SEFI 36th-academia. edu . http://www.georgesnahas.com/gn/?p=1770. 
National Council of Teachers of Mathematics. (1991). Professional standards for teaching mathematics. Reston, VA: National Council of Teachers of Mathematics.Google Scholar.

Ngozi, H. (2009). Metacognitive strategies on classroom participation and student achievement in senior secondary school science classrooms. Science Education International, 20 (12), .25-31. http://www.icaseonline.net/sei/les/p2.pdf 13.

OECD (2000). Measuring student knowledge and skills: a new framework for assessment. Paris: OECD. http://gpseducation.oecd.org

Parra-frutos, I. (2009). The behaviour of the modified levene's test when data are not normally distributed. Computational Statistics, 24(4), 671-693. doi:http://dx.doi.org.ezproxy.aub.edu.lb/10.1007/s00180-0090154-Z

Perry, C. (1998). A structured approach for presenting theses. Australasian Marketing Journal, 6(1), 63-85. doi:10.1016/S1441-3582(98)70240-X

Piaget, J. (1976). The child's conception of the world. Totowa, NJ:Littlefield, Adams

Polya, G. (1973). How to solve it. Princeton: Princeton University Press.

Schoenfeld, A. H. (1985). Metacognitive and epistemological issues in mathematical understanding. In E. A. Silver (Ed.), Teaching and learning mathematical problem solving: Multiple research perspectives. Hillsdale, NJ: Lawrence Erlbaum Associates.

Robertson, K. (2006). Increase student interaction with "Think-Pair-Shares" and "Circle Chats". Colorin: Colorado. Retrieved from http://www.colorincolorado.org/ article/13346

Schroeder, T. L., \& Lester, F. K., Jr. (1989). Developing understanding in mathematics via problem solving. In P. Trafton, A. Shulte, \& National Council of Teachers of Mathematics (Eds), New directions for elementary school mathematics (pp 31-42). The National Council of Teachers of Mathematics.

Schoolcraft, N. K. (2015). Think-pair-think-share and language in the high school geometry classroom (Publication No. 3738778) [Doctoral dissertation, Indiana University]. Available from ProQuest Dissertations \& Theses Global. (1746694408).

Smith, S. W., Daunic, A. P., \& Taylor, G. G. (2007). Treatment fidelity in applied educational research: Expanding the adoption and application of measures to ensure evidence-based practice. Education and Treatment of Children, 30(4), 121-134. http://doi.org/10.1353/etc.2007.0033

Steinberg, R. M., Empson, S. B., \& Carpenter, T. P. (2004). Inquiry into children's mathematical thinking as a means to teacher change. Journal of Mathematics Teacher Education, 7(3), 237-267. doi:10.1023/B:JMTE.0000033083.04005.d3.

Tambychik, T., \& Meerah, T. S. M. (2010). Students' difficulties in mathematics problem-solving: What do they say? Procedia, Social and Behavioral Sciences, 8, 142- 151. doi:10.1016/j.sbspro.2010.12.020

Tambychik, T., Meerah, T. S. M., \& Aziz, Z. (2010). Mathematics skills difficulties: A mixture of intricacies. Procedia, Social and Behavioral Sciences, 7, 171- 180. doi:10.1016/j.sbspro.2010.10.025.

TIMSS \& PIRLS (2016). International results. https://timssandpirls.bc.edu

TIMSS \& PIRLS (2019). International results. https://timss2019.org/reports/achievement/\#math-8

Türkçapar, M.H., Kahraman, M.S., \& SargýnA.E. (2015). Guided discovery with socratic questioning. Bilişsel Davranışçı Psikoterapi Araştırmalar Dergisi, 4(1), 47-53. doi:10.5455/JCBPR.188198

Van De Walle, J. Karp, K. S., \& Bay-Williams, J. M. (2016). Elementary and middle school mathematics: Teaching developmentally Pearson Education.

Verschaftel, L., Greer. B., \& De Corte, E. (2000). Making sense of word problems. Lisse, The Netherlands: Swets \& Zeitlinger

Vygotsky, L. (1986). Thought and language. Cambridge, MA: MIT Press

Vygotsky, L. S. (1978). Mind in society: The development of higher psychological processes. Cambridge, MA: Harvard University Press.

Wilberding, E. (2019). Socratic methods in the classroom: Encouraging critical thinking and problem solving through dialogue. Naperville: Sourcebooks.

Wolf, M. K., \& Leon, S. (2009). An investigation of the language demands in content assessments for English Language Learners. Educational Assessment, 14, 139- 159. doi:10.1080/10627190903425883

Wright, D. B. (2003) Making friends with your data: improving how statistics are conducted and reported. British Journal of Educational Psychology, 73 (1), pp. 123-36.

Zoubi, Ali. (2014). Effective teaching strategy based on mathematical problem solving in the development of number sense among Teacher students in Jordan. Muta for Research and Studies - Humanities and Social Sciences-Jordan (29), 167-204.

Interviews

Nehme Mahfoud (Mathematics secondary teacher) (Call interview) November 20, 2018 @ 14:13 


\section{About Authors:}

Lina Ramez Amanatallah has over 30 years experience in teaching Mathematics at the elementary level in the private sector and more than 10 years experience in teaching Education at the Lebanese International UniversityTripoli. She taught courses related to the methods of teaching in general and teaching mathematics in particular. She received her BA in Psychology and her Teaching Diploma in Elementary Education from the American University of Beirut (1988) and her Master's degree in Education from the University of Balamand. She fulfilled the requirements of the PhD program at the University of Saint Joseph- Beirut.

Dr. Nehme Safa is an associate professor at the University of Saint Joseph- Beirut- Faculty of Educational Sciences. He is responsible for carrying out research projects at the Educational Research Laboratory, Faculty of Educational Sciences. Dr. Safa teaches courses at the graduate level and gives seminars at the post graduate level. 